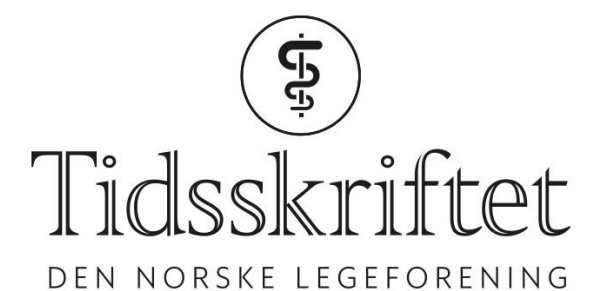

DEN NORSKE LEGEFORENING

\title{
Let's talk about sex - uten øvre aldersgrense
}

LEDER

NORA JOHANSEN

E-post: nora.johansen@sshf.no

Nora Johansen er ph.d., overlege og postdoktor ved Avdeling for obstetrikk og gynekologi, Sørlandet sykehus Arendal.

Forfatteren har fylt ut ICMJE-skjemaet og oppgir ingen interessekonflikter.

Vi må tørre å spørre om pasientens sexliv.

«Heldigvis er det ingen problemer med sexen!» sa den nærmere 80 år gamle kvinnen idet hun var på vei ut døra etter en gynekologisk undersøkelse. Hun hadde hatt flere underlivsoperasjoner, en rekke medisinske sykdommer og det jeg kanskje ville kalt mye komorbiditet. Så stakk hun hodet inn av døra igjen og sa: «Vi er så gode mot hverandre, skjønner du ...». Forventet jeg at hun ikke hadde et sexliv? En uprofesjonell antakelse! Nei, det var enda verre, jeg hadde ikke tenkt på det engang.

Leger spør sjelden om pasientenes seksualliv, selv ikke når vi anbefaler en medisin eller planlegger en operasjon som mest sannsynlig påvirker sexlivet. Når heller ikke pasientene tar det opp, blir det vanskelig å gi god hjelp.

Så mye som 8o \% av kvinner mellom 18 år og 67 år hadde minst ett vedvarende seksuelt problem, ifølge en norsk undersøkelse fra 2010. Manglende sexlyst (30-45\%) og orgasmeproblemer (20-30 \%) var de vanligste, og forkom hyppigst i 30-, 50- og 6o-årene. Tørre slimhinner og smerter var vanligst hos dem over 50 år (1). Seksuallivet, og hvorvidt seksuelle problemer oppleves som belastende, svinger i løpet av livet. Unge kan føle seg usikre på egen seksualitet og de kan la seg stresse av forventninger. Det hjelper lite at kvinnekroppen ofte framstilles etter idealer som er uoppnåelige for de fleste. I 3o-årene kan foreldrerollen og hektisk hverdagsliv gjøre det vanskelig å ha overskudd til sex. Dette bedres gjerne i 40-årene.

Det er bare pasienten selv som vet om et seksuelt problem er belastende. Derfor må vi spørre

God seksuell helse kan ha helt ulike betydninger fra person til person. En kvinne kan være seksuelt aktiv ved å ha sex med seg selv, med en annen kvinne eller med en mann, og det er bare pasienten selv som vet om et seksuelt problem er belastende. Derfor må vi spørre, men vi må spørre åpent og gi rom for alle typer svar.

Heldigvis tenker vi ikke lenger at sex er forbeholdt de unge. Med økende levealder har kvinner nesten halve livet igjen etter overgangsalderen, og for mange er seksuell aktivitet 
viktig for god livskvalitet. I en spørreundersøkelse blant norske kvinner i alderen 6o-75 år svarte $74 \%$ at de var seksuelt aktive (masturbering, samleie, beføling eller kyssing) (2). Samtidig oppga 52 \% orgasmeproblemer, $41 \%$ manglende sexlyst og $39 \%$ problemer med tørre slimhinner (3).

Hvilke behandlingsmuligheter finnes for eldre kvinner med seksuelle problemer? Ved tørre slimhinner kan nesten alle bruke østrogen i skjeden uten fare for bivirkninger (4). Lokal fuktighetsgel er et østrogenfritt alternativ. Testosterongel lagd for menn kan doseres forsiktig (maks $5 \mathrm{mg} / \mathrm{dag}$ ) og kan øke sexlysten (5). Hormonbehandling kan hjelpe mot overgangsplager, mens noen bør henvises til sexolog.

Med $ø$ kende levealder har kvinner nesten halve livet igjen etter overgangsalderen, og for mange er seksuell aktivitet viktig for god livskvalitet

Det finnes altså hjelp å få, men de færreste spør selv, og bare 14 \% hadde opplevd at legen spurte om sexlivet deres (6). Grunner til at legen ikke spør eldre kvinner om sexlivet, kan være forlegenhet, tidsnød, antakelse om at eldre kvinner ikke har sex eller bekymring for å invadere pasientens privatliv. Samtidig vet vi at det er lettere for pasienter å ta opp seksuelle problemer dersom legen har spurt om sex ved en tidligere anledning (6). Forlegenhet er også en viktig grunn til at pasienter ikke tar opp seksuelle problemer. Andre tenker at dette er noe de må regne med i sin alder, mens noen ikke synes at problemene er så belastende at det er verdt å ta opp.

Ved å spørre om pasientens sexliv vil vi kunne avdekke problemer som kan behandles, men vel så viktig viser vi oss som trygge relasjoner som pasienten kan komme tilbake til hvis hun ønsker å snakke om sex. Og hvis man som lege føler man har trådt feil, kan man si «beklager hvis du syntes det var ubehagelig at jeg tok opp dette, det var ikke meningen». For vi kan ikke la egen forlegenhet komme i veien for kvinners seksuelle helse.

\section{LITTERATUR:}

1. Traeen B, Stigum H. Sexual problems in 18-67-year-old Norwegians. Scand J Public Health 2010; 38 : 445-56. [PubMed][CrossRef]

2. Træen B, Štulhofer A, Janssen E et al. Sexual activity and sexual satisfaction among older adults in four European countries. Arch Sex Behav 2019; 48: 815-29. [PubMed][CrossRef]

3. Graham CA, Štulhofer A, Lange T et al. Prevalence and predictors of sexual difficulties and associated distress among partnered, sexually active older women in Norway, Denmark, Belgium, and Portugal. Arch Sex Behav 2020; 49: 2951-61. [PubMed][CrossRef]

4. Lethaby A, Ayeleke RO, Roberts H. Local oestrogen for vaginal atrophy in postmenopausal women. Cochrane Database Syst Rev 2016; 2016: CDoo150o. [PubMed][CrossRef]

5. Johansen N, Lindén Hirschberg A, Moen MH. The role of testosterone in menopausal hormone treatment. What is the evidence? Acta Obstet Gynecol Scand 2020; 99: 966-9. [PubMed][CrossRef]

6. Hinchliff S, Carvalheira AA, Štulhofer A et al. Seeking help for sexual difficulties: findings from a study with older adults in four European countries. Eur J Ageing 2019; 17: 185-95. [PubMed][CrossRef]

Publisert: 7. mars 2021. Tidsskr Nor Legeforen. DOI: 10.4045/tidsskr.21.0130

(C) Tidsskrift for Den norske legeforening 2020. Lastet ned fra tidsskriftet.no 